\title{
Geographic patterns of Early Holocene New World dental mor- phological variation
}

\author{
Christopher M. Stojanowski ${ }^{1}$, Kent M. Johnson ${ }^{1}$, William N. Duncan ${ }^{2}$ \\ ${ }^{1}$ Center for Bioarchaeological Research, School of Human Evolution and Social Change, Arizona State University, \\ Tempe, AZ 85287 \\ 2 Department of Sociology and Anthropology, East Tennessee State University, Johnson City, TN 37614-1702
}

Keywords: New World, Dental Morphology, Paleoindian, Paleoamerican

ABSTRACT Dental anthropology played a seminal role in early studies of the peopling of the New World, and was a foundation of the early three wave model proposed by Greenberg, Turner and Zegura. In recent years, however, developments in anthropological genetics, craniometry, and archaeological discoveries have largely omitted dental anthropology from debates regarding Native American origins. Here we consider this situation and reassert dental anthropology's relevance to the topic by presenting an interindividual analysis of Paleoindian and Paleoamerican dentitions. A small set of dental morphological variables was used to estimate Gower similarity coefficients between individual specimens. The resulting similarity matrix was ordinated using

Dental morphology played a key role in the development of the tripartite model of New World population origins (Greenberg et al., 1985, 1986; Turner, 1971, 1983, 1984, 1985a, b, 1986). While this model still provides a viable explanation for the settlement of the Western Hemisphere (EstradaMena et al., 2010; Reich et al., 2012), recent advances in anthropological genetic sampling protocols, amplification techniques, and analytical approaches have provided more nuanced understandings of New World population structure. These include models that propose a single origin from an Asian source population isolated in Beringia prior to colonization of the Americas (Estrada-Mena et al., 2010; Fagundes et al., 2008; Kitchen et al., 2008; Mulligan et al., 2008; Schroeder et al., 2007, 2009; Tamm et al., 2007; Wang et al., 2007), dual origin models (Gilbert et al., 2008; Rasmussen et al., 2010), and more complex scenarios involving one or more migrations from a heterogeneous source population - possibly via different migration routes - followed by bidirectional gene flow between Asia and the Americas that lasted several thousand years (González-José and Bortolini, 2011; multidimensional scaling; all analyses were performed in Clustan v. 7.05. While results should be considered preliminary, patterns of variation suggest morphological similarity along both coasts of North and South America with a somewhat distinct grouping of North American Paleoindians deriving from more inland portions of the continent. This pattern is consistent with recent genetic scenarios, notably the bicoastal model presented by O'Rourke and Raff (2010), which indicates that Paleoindians may have taken multiple migration routes from Beringia, moving along both coasts as well as through the ice free corridor. Future studies may build on this work to reintegrate dental data and analysis into research concerning the peopling of the New World.

Kumar et al., 2011; Mazières, 2011; O'Rourke and Raff, 2010; Perego et al., 2009, 2010; Ray et al., 2010; Rubicz et al., 2010; Tamm et al., 2007). In addition, recent archaeological discoveries have largely supplanted the "Clovis First" model which dominated Paleoindian research for several decades (e.g., Adovasio and Pedler, 2004; Dillehay, 1997; Goebel et al., 2008; Waters et al., 2011) and which coincided strongly with the predictions of the tripartite model. Discoveries of Early Holocene skeletal material from South America, combined with advances in phenotypic data analysis better grounded in evolutionary processes, have also generated new views on the peopling of the Americas (e.g., de Azevedo et al., 2011; Gonzalez et al., 2010; González-José and Bortolini, 2011; González-

Correspondence to:

Christopher M. Stojanowski

900 S. Cady Mall

School of Human Evolution and Social Change

Arizona State University

Tempe, AZ 85287

cstojano@asu.edu 
José et al., 2001, 2008; Mena L. et al., 2003; Neves et al., 2004, 2005; Perez et al., 2007, 2009; Pucciarelli et al., 2003, 2006, 2008, 2010).

Despite the historical importance of dental anthropology in the First Americans debate, recent synthetic surveys of the literature (e.g., Dillehay, 2009; Fiedel, 2004; Goebel et al., 2008; GonzálezJosé and Bortolini, 2011; Mazières, 2011; O'Rourke, 2011; O’Rourke and Raff, 2010; Pitblado, 2011) indicate that dentition has lost its relevance in these discussions. In fact, the most recent literature review fails to include a single citation for papers using dental morphology as a basis for inferring New World population history (Pitblado, 2011). There are many reasons why this may be. However, one inescapable fact is that genetic, archaeological, and craniometric specialists have adopted new research approaches and methods over the last decade, including more sophisticated types of data capture and analysis, which increase the specificity and nuance of their interpretations. This is evidenced by the incorporation of inferential analyses that access more complex evolutionary models in the analysis of phenotypic size and shape. Dental anthropology on the other hand has largely maintained a focus on population-based frequency analyses and, in particular, the sinodont/sundadont dichotomy (see Turner, 1990).

Our purpose here is not to engage existing debates about the utility of the sinodont/sundadont model or the relationship between specific Paleoindian or Paleoamerican specimens and the morphological complex associated with sinodonty or sundadonty (e.g., Chatters, 2000; Haydenblit, 1996; Lahr and Haydenblit, 1995; Powell, 1993, 1995, 2005; Sutter, 1997, 2005; Turner, 2002). Here, we adopt a more paleontological focus that recognizes the relative dearth of existing Early Holocene material from North and South America and the singleton status of much of the North America Paleoindian record. Our primary goal in this paper is to move the field forward by demonstrating that fragmentary specimens and small data sets can be used to consider hypotheses about the temporal and spatial structure of New World phenotypic variation using a research approach distinct from frequency-based assessments. We make no claims that one approach is necessarily better than the other. We only demonstrate the potential of different approaches for complementing one another and engaging new models of interpretation that add nuance to the literature.

\section{MATERIALS AND METHODS}

Using existing morphological data, our purpose in this paper is to determine whether Early Holocene (Paleoindian and Paleoamerican) interindividual dental morphological variation is geographically structured. That is, we consider whether inter-individual patterns of affinity reproduce geographic spatial structure, and if so, whether dental variation corresponds with recent hypothesized migration scenarios into the New World, such as the bi-coastal model proposed by O'Rourke and Raff (2010), which accommodates multiple, possibly contemporaneous migration routes from Beringia through the ice-free corridor and along both coasts. We mined published raw dental morphological data from confirmed Paleoindian and Paleoamerican dentitions (see Chatters, 2000; Jenks, 1937; Owsley et al., 2010; Potter et al., 2011; Powell and Rose, 1999; Turner, 1992; Young, 1988) and verified the Early Holocene age of these specimens (> 7500bp). These data are summarized in Table 1. Raw trait scores were used to generate inter-individual similarity statistics using Clustan v. 7.05 (Wishart, 2004). Gower coefficients were used because they allow for missing data (obviating data imputation) and mixed scale data types (ordinal and binary). Similarities were ordinated and visualized using multidimensional scaling in two dimensions set at 500 runs and iterations. Variables were removed from the final analysis based on frequency of observation (variables that were too sparse were removed) and if the variable demonstrated insufficient trait score variability among individuals. Those variables that demonstrated no inter-individual variation or were autapomorphic were removed from the raw dataset prior to the calculation of similarities. In addition, traits that were clearly redundant (for example, Carabelli's scores for maxillary M1s and M2s) were reduced, where the trait that was kept was largely decided based upon data density rather than notions of key tooth representation. Individual Paleoindian or Paleoamerican dentitions were omitted if they preserved too few recorded scores, although we note the rarity of North American specimens required more consideration of trait exclusion to maximize the coverage of the 


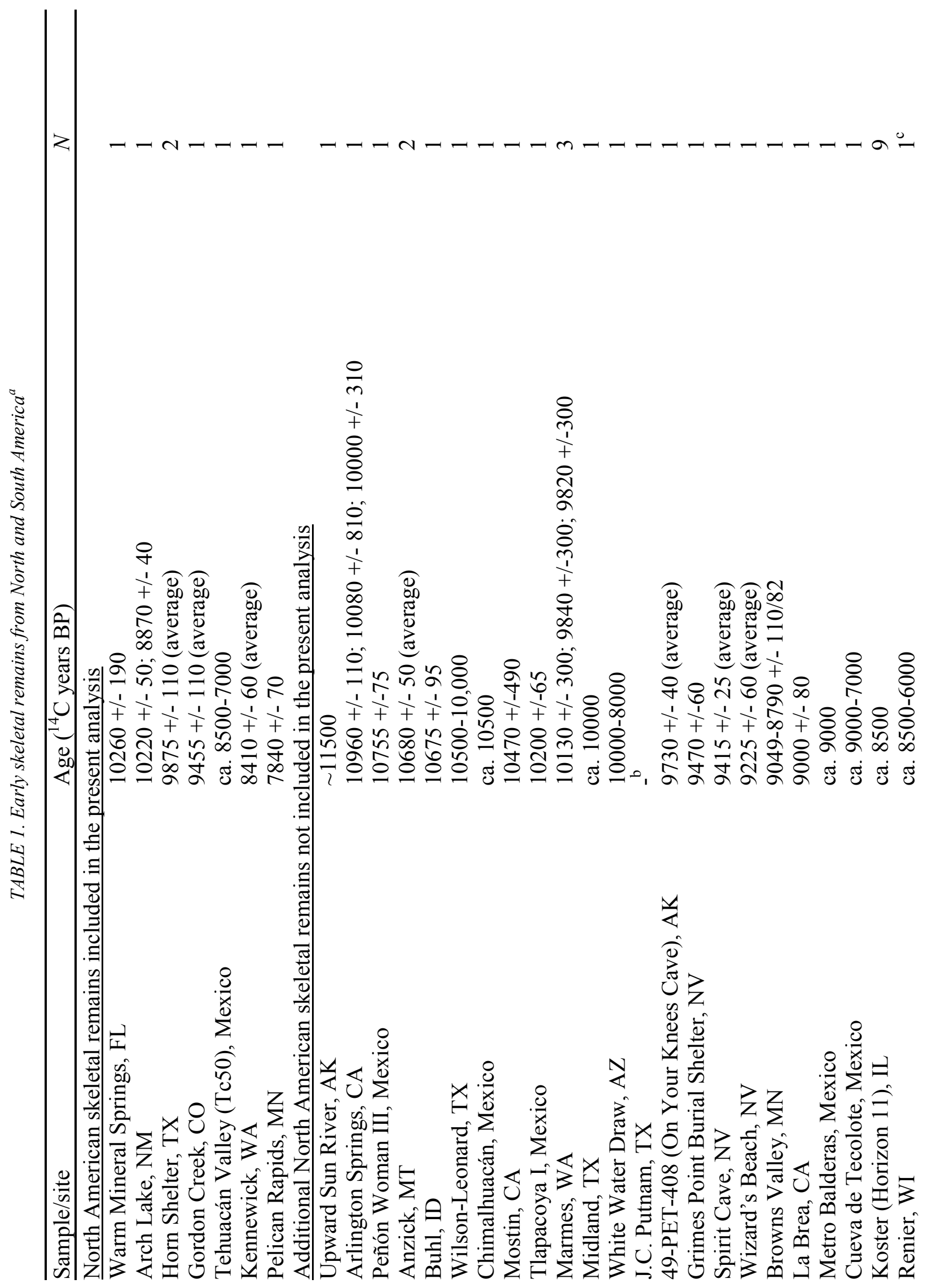




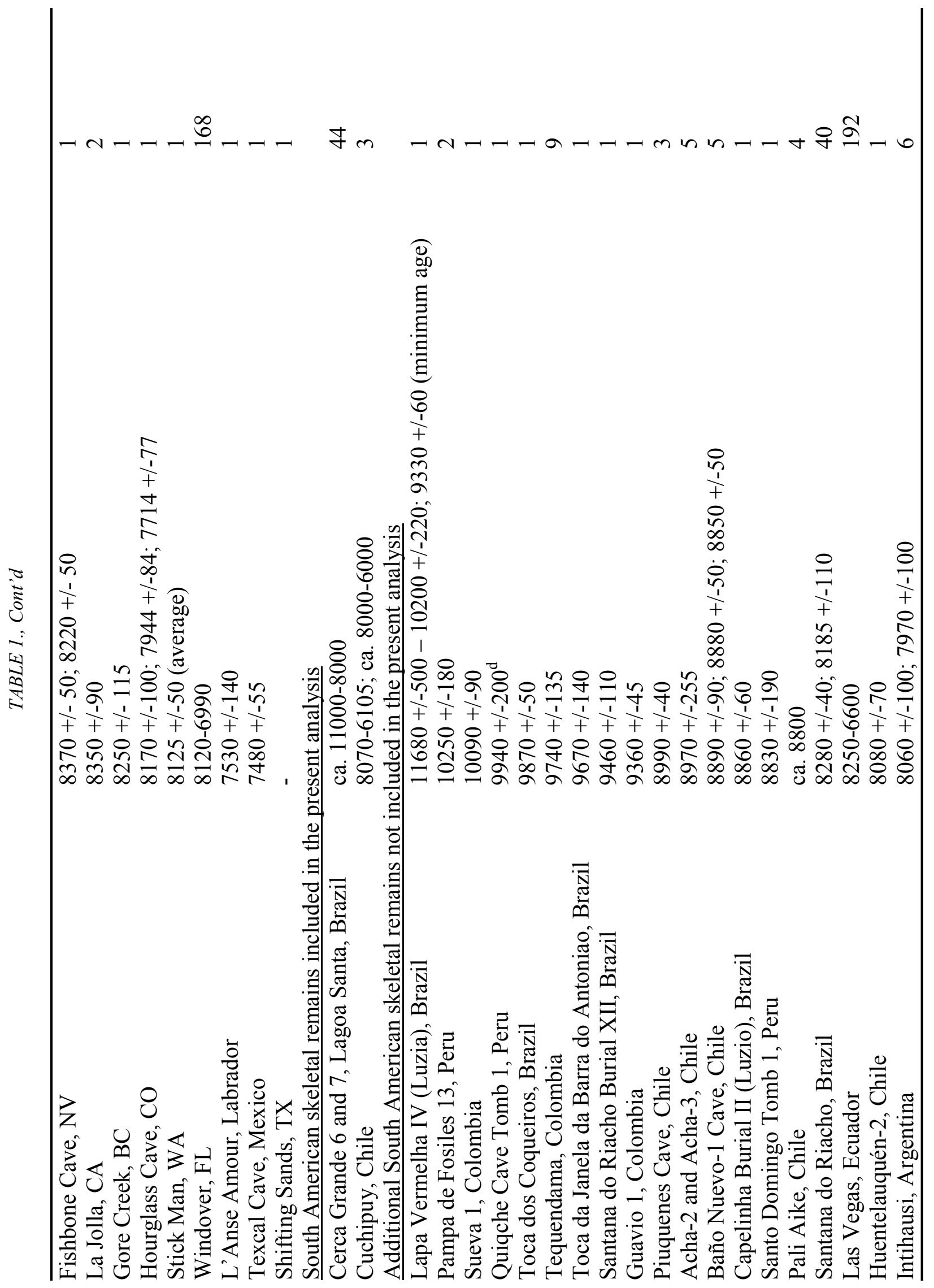




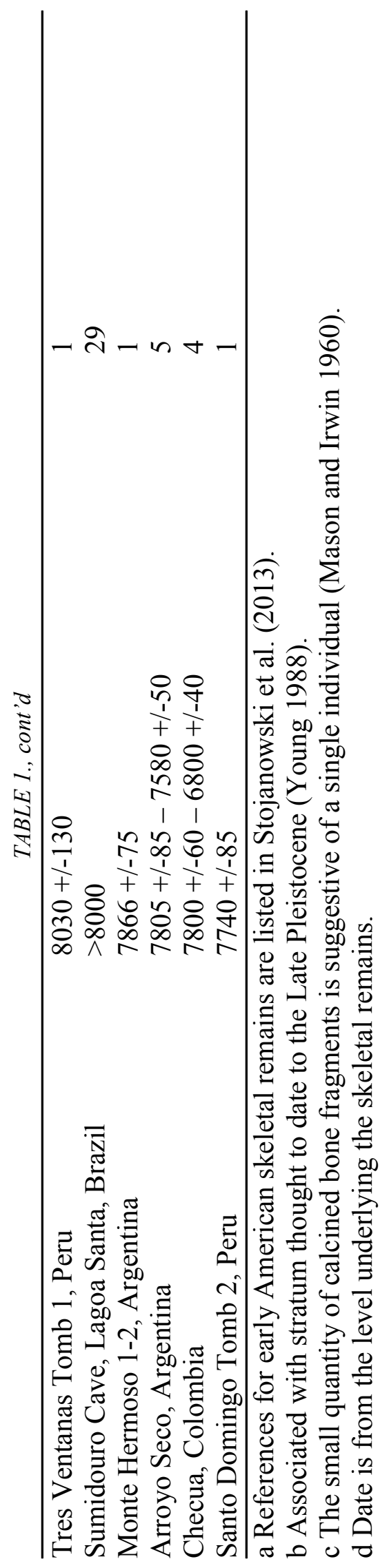

Fig. 1. Map of North and South American showing the location of Paleoindian and Paleoamerican specimens used in this analysis: 1 . Arch Lake; 2. Gordon Creek; 3. Horn Shelter No. 2; 4. Kennewick; 5. Pelican Rapids; 6. Tehuacán (Tc502); 7. Warm Mineral Springs; 8. Cuchipuy; 9. Lagoa Santa.

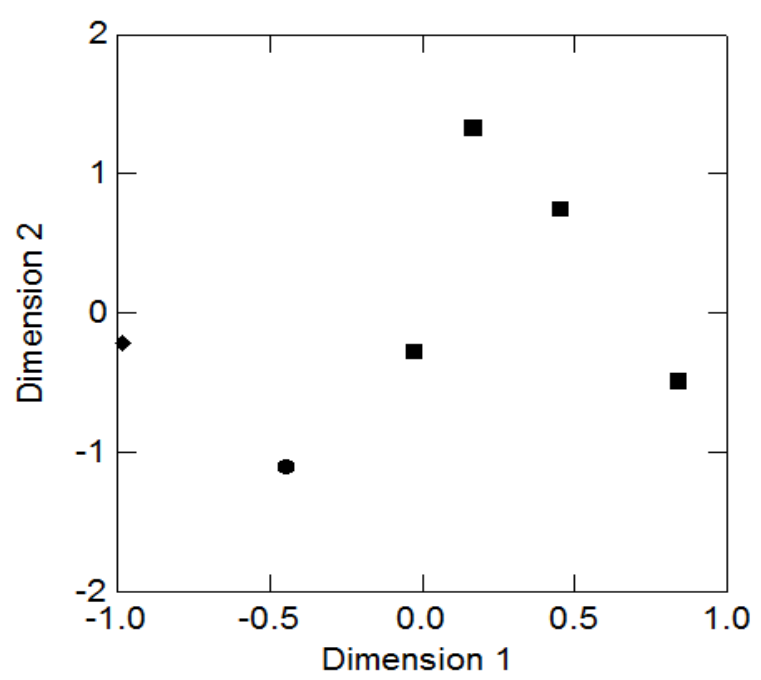

Fig. 2. Multidimensional scaling of Gower similarity coefficients calculated from eight dental morphological traits for confirmed North American Paleoindians. Icons represent geographic divisions: circle $=$ western North America (Kennewick), square $=$ central North America, diamond $=$ eastern North America (Warm Mineral Springs). 


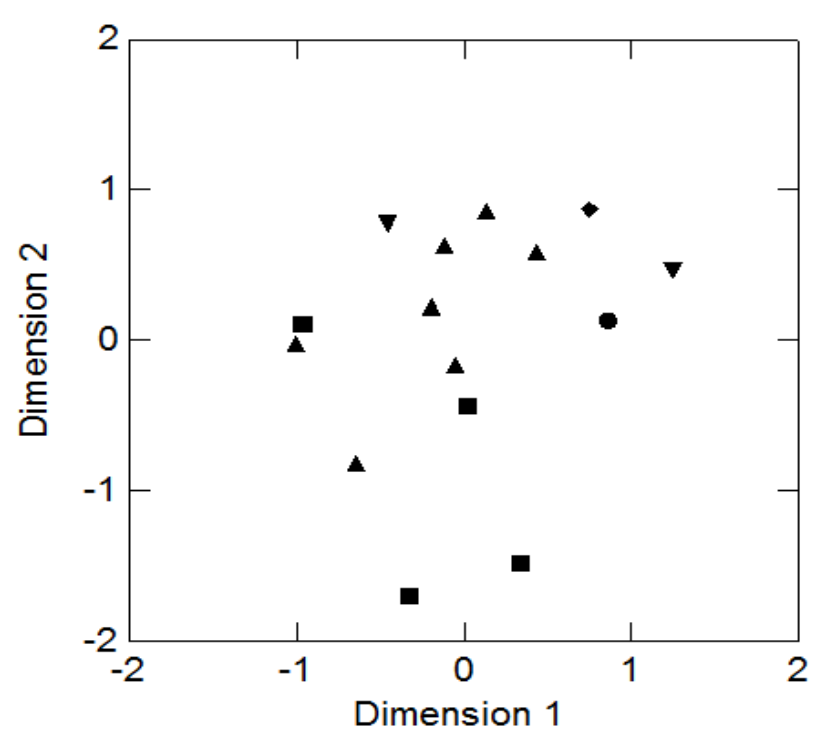

Fig. 3. Multidimensional scaling of Gower similarity coefficients calculated from six maxillary dental morphological traits for confirmed North and South American Paleoindians and Paleoamericans. Icons represent geographic divisions: circle $=$ Mexico, diamond $=$ eastern North America, square $=$ central North America, upward triangle = eastern South America, downward triangle $=$ western South America.

continent so that assessments of geographic structure were possible.

\section{RESULTS}

Because the majority of South American dentitions lacked paired maxillae and mandibles we first consider patterns of inter-individual variation among North American Paleoindian specimens. Despite the number of possible Paleoindian specimens (see Table 1) we were only able to include data from six individuals: Pelican Rapids, Gordon Creek, Warm Mineral Springs, Arch Lake, Horn Shelter 2, and Kennewick. These six dentitions range from Washington to Florida with most samples deriving from the middle of the continent (Figure 1). Based on data preservation, we included eight dental morphological traits in the calculation of Gower similarity coefficients (UI1 shoveling, UM1 hypocone, UM1 Carabelli, UM1 enamel extension, UP1 root number, UM2 root number, LM2 cusp number, and LM2 root number). Results of the multidimensional scaling are presented in Figure 2. There is some evidence for geographic pat- terning. For example, the four central North American samples (non-coastal) form a weak cluster in the upper right quadrant while both coastal samples plot in the negative half of both axes. This could be consistent with a single population bifurcating and migrating quickly down the Atlantic and Pacific coasts of North America with a distinct population colonizing the middle of the continent.

Inclusion of South American Paleoamerican dentitions required using only six maxillary traits (UI1 shoveling, UM1 hypocone, UM1 Carabelli, UM1 enamel extension, UP1 root number, and UM2 root number). The sample included the same Paleoindian specimens as above (with the exception of Kennewick which had to be excluded), a single individual from Mexico (Tehuacán Tc50-2), two individuals from western South America (Cuchipuy), and seven individuals from eastern South America (Lagoa Santa). Results are presented in Figure 3. Although the clustering tendency was more abstract there does appear to be some geographic patterning evident in this figure. For example, the dentitions from western South America, eastern South America, Mexico, and eastern North America dominate the positive half of the dimension two axis, while dentitions from noncoastal North American Paleoindians dominate the negative half of the dimension two axis. Another way to consider this is that coastal samples from both North and South America cluster in the positive half of the dimension two axis while interior samples (all from North America) plot in the negative half of the dimension two axis. Remarkably, the overall pattern of variation does not change with the addition of South American data. These analyses, therefore, may reflect a possible bi-coastal migration of Early Holocene populations along both the Pacific and Atlantic coasts of North and South America with a somewhat distinct population inhabiting the interior of North America (perhaps involving the ice-free corridor), consistent with $\mathrm{O}^{\prime}$ Rourke and Raff's (2010) model.

\section{CONCLUSION}

Recent advances in archaeology, anthropological genetics, and human craniometry have enhanced our understanding of New World population origins and migration dynamics within 
the Western Hemisphere. For a variety of reasons, dentition has figured less prominently in recent First American debates to the point that the most recent literature review of this expansive literature ignores dentition entirely (Pitblado, 2011). This is unfortunate. Here we have tried to demonstrate that a specimen-specific approach to Paleoindian and Paleoamerican dental morphology may have some merit. In particular, using a small series of dentitions and morphological traits our results suggest a similar dental phenotype among coastal populations of the Early Holocene New World with a somewhat distinct morphology among central, non-coastal North American dentitions. Here, we have emphasized population structure and evolution as the primary explanatory mechanism; however, differential selection pressures related to distinct coastal/inland diets should also be considered. In closing, we want to stress how preliminary these results are. As indicated in Table 1 there is now an abundance of Paleoindian and Early Archaic period sites and specimens in the Americas and our analyses utilize only a small number of traits for a small number of individuals. Nevertheless, we hope our results show enough promise to justify a more comprehensive survey of dental morphology in these specimens, including the use of recent developments in threedimensional data capture and incorporation of evolutionary developmental principles in the assessment of evolutionary signatures of human dentition.

\section{LITERATURE CITED}

Adovasio JM, Pedler DR. 2004. Pre-Clovis sites and their implications for human occupation before the last glacial maximum. In: Madsen DB, editor. Entering America: Northeast Asia and Beringia before the Last Glacial Maximum. Salt Lake City, Utah: University of Utah Press. p. 139-158.

Chatters JC. 2000. The recovery and the first analysis of an early Holocene human skeleton from Kennewick, Washington. Am Antiq 65: 291-316.

de Azevedo S, Nocera A, Paschetta C, Castillo L, González M, González-José R. 2011. Evaluating microevolutionary models for the early settlement of the New World: the importance of recurrent gene flow with Asia. Am J Phys Anthropol 146:539-552.
Dillehay TD. 1997. Monte Verde: A Late Pleistocene Settlement in Chile, vol. 2: The Archaeological Context and Interpretation. Washington, D.C.: Smithsonian Institution Press.

Dillehay TD. 2009. Probing deeper into first American studies. Proc Natl Acad Sci USA 106: 971-978.

Estrada-Mena B, Estrada FJ, Ulloa-Arvizu R, et al. 2010. Blood group $\mathrm{O}$ alleles in Native Americans: implications in the peopling of the Americas. Am J Phys Anthropol 142:85-94.

Fagundes NJR, Kanitz R, Eckert R, et al. 2008. Mitochondrial population genomics supports a single pre-Clovis origin with a coastal route for the peopling of the Americas. Am J Hum Gen 82:583-592.

Fiedel SJ. 2004. The Kennewick follies: "new" theories about the peopling of the Americas. J Anthropol Res 60:75-110.

Gilbert MTP, Kivisild T, Grønnow B, et al. 2008. Paleo-Eskimo mtDNA genome reveals matrilineal discontinuity in Greenland. Science 320:1787 -1789 .

Goebel T, Waters MR, O'Rourke DH. 2008. The Late Pleistocene dispersal of modern humans in the Americas. Science 319:1497-1502.

Gonzalez PN, Perez SI, Bernal V. 2010. Ontogeny of robusticity of craniofacial traits in modern humans: a study of South American populations. Am J Phys Anthropol 142:367-379.

González-José R, Bortolini MC. 2011. Integrating different biological evidence around some microevolutionary processes: bottlenecks and Asian-American arctic gene flow in the New World settlement. Evolution: Education and Outreach 4:232-243.

González-José R, Bortolini MC, Santos FR, Bonatto SL. 2008. The peopling of America: craniofacial shape variation on a continental scale and its interpretation from an interdisciplinary view. Am J Phys Anthropol 137:175-187.

González-José R, Dahinten S, Hernández M. 2001. The settlement of Patagonia: a matrix correlation study. Hum Biol 73:233-248.

Greenberg JH, Turner CG II, Zegura SL. 1985. Convergence of evidence for the peopling of the Americas. Collegium Antropologicum, 9: 33-42.

Greenberg JH, Turner CG II, Zegura SL. 1986. The settlement of the Americas: a comparison son of the linguistic, dental, and genetic evidence. Curr Anthropol 27:477-497. 
Haydenblit R. 1996. Dental variation among four prehispanic Mexican populations. Am J Phys Anthropol 100:225-246.

Jenks AE. 1937. Minnesota's Browns Valley Man and Associated Burial Artifacts. Memoirs of the American Anthropological Association, No. 49. Menasha, WI, American Anthropological Association.

Kitchen A, Miyamoto MM, Mulligan CJ. 2008. A three-stage colonization model for the peopling of the Americas. PLoS One 3:e1596.

Kumar S, Bellis C, Zlojutro M, et al. 2011. Large scale mitochondrial sequencing in Mexican Americans suggests a reappraisal of Native American origins. BMC Evol Biol 11:293.

Lahr MM, Haydenblit R. 1995. Traces of ancestral morphology in Tierra del Fuego and Patagonia. Am J Phys Anthropol 38: 128.

Mason R, Irwin C. 1960. An Eden-Scottsbluff burial in Northeastern Wisconsin. Am Antiq 26:4357.

Mazières S. 2011. Towards a reconciling model about the initial peopling of America. Comptes Rendus Biologies 334:497-504.

Mena LF, Reyes O, Stafford TW Jr., Southon J. 2003. Early human remains from Baño Nuevo-1 cave, central Patagonian Andes, Chile. Quat Intl 109-110: 113-121.

Mulligan CJ, Kitchen A, Miyamoto MM. 2008. Updated three-stage model for the peopling of the Americas. PLoS One 3:e3199.

Neves WA, González-José R, Hubbe $\mathrm{M}$, et al. 2004. Early Holocene human skeletal remains from Cerca Grande, Lagoa Santa, Central Brazil, and the origins of the First Americans. World Archaeol, 36:479-501.

Neves WA, Hubbe M, Okumura MM, et al. 2005. A new early Holocene human skeleton from Brazil: implications for the settlement of the New World. J Hum Evol 48:403-414.

O'Rourke DH. 2011. Contradictions and concordances in American colonization models. Evolution: Education and Outreach 4:244-253.

O'Rourke DH, Raff JA. 2010. The human genetic history of the Americas: the final frontier. Curr Biol 20:R202-R207.

Owsley DW, Jodry MA, Stafford TW Jr., Haynes Jr. CV, Stanford DJ. 2010. Arch Lake Woman: Physical Anthropology and Geoarchaeology. College Station, Texas A\&M University Press.

Perego UA, Achilli A, Angerhofer N, et al. 2009.
Distinctive Paleo-Indian migration routes from Beringia marked by two rare mtDNA haplogroups. Curr Biology 19:1-8.

Perego U.A., Angerhofer N, Pala M, et al. 2010. The initial peopling of the Americas: a growing number of founding mitochondrial genomes from Beringia. Genome Res 20:1174-1179.

Perez SI, Bernal V, Gonzalez PN. 2007. Morphological differentiation of Aboriginal human populations from Tierra del Fuego (Patagonia): implications for South American peopling. Am J Phys Anthropol 133:1067-1079.

Perez SI, Bernal V, Gonzalez PN, Sardi ML, Politis GG. 2009. Discrepancy between cranial and DNA data of early Americans: implications for American peopling. PLoS ONE 4:1-11.

Pitblado BL. 2011. A tale of two migrations: reconciling recent biological and archaeological evidence for the Pleistocene peopling of the Americas. J Archaeol Res 19:327-375.

Potter BA, Irish JD, Reuther JD, Gelvin- Reymiller

C, Holliday VT. 2011. A terminal Pleistocene child cremation and residential structure from eastern Beringia. Science 331:1058-1062.

Powell JF. 1993. Dental evidence for the peopling of the New World: some methodological considerations. Hum Biol 65: 799-819.

Powell JF. 1995. Dental Variation and Biological Affinity Among Middle Holocene Human Populations in North America. Ph.D. dissertation, Department of Anthropology, Texas A\&M University.

Powell JF. 2005. The First Americans: Race, Evolution, and the Origin of Native Americans. Cambridge: Cambridge University Press.

Powell JF, Rose JC. 1999. Report on the Osteological Assessment of the "Kennewick Man" Skeleton (CENWW.97.Kennewick)". US Department of the Interior Report. Available at http:/ / nps.aad.kennewick.org/kennewick.

Pucciarelli HM, Sardia ML, Jimenez López JC, Serrano Sanchez C. 2003. Early peopling and evolutionary diversification in America. Quaternary Intl 109-110:123-132.

Pucciarelli HM, Neves WA, González-José R, Sardia ML, Ramirez Rozzie F, Struck A, Bonilla MY. 2006. East-West cranial differentiation in preColumbian human populations of South America. Homo 57:133-150.

Pucciarelli HM, González-José R, Neves WA, Sardia ML, Ramirez Rozzie F. 2008. East-West cranial 
differentiation in pre-Columbian populations from Central and North America. J Hum Evol 54:296-308.

Pucciarelli HM, Perez SI, Politis GG. 2010. Early Holocene human remains from the Argentinean Pampas: additional evidence for distinctive cranial morphology of early South Americans. Am J Phys Anthropol 143:298-305.

Rasmussen M, Li Y, Lindgreen S, et al. 2010. Ancient human genome sequence of an extinct Palaeo-Eskimo. Nature 463:757-762.

Ray N, Wegman D, Fagundes NJR, et al. 2010. A statistical evaluation of models for the initial settlement of the American continent emphasizes the importance of gene flow with Asia. Molec Biol and Evol 27:337-345.

Reich D, Patterson N, Campbell D, et al. 2012. Reconstructing Native American population history. Nature 488:370-374.

Rubicz R, Melton PE, Spitsyn V, Sun G, Deka R, Crawford MH. 2010. Genetic structure of native circumpolar populations based on autosomal, mitochondrial, and Y chromosome DNA markers. Am Phys Anthropol 143:62-74.

Schroeder KB, Jakobsson M, Crawford $\mathrm{MH}$, et al. 2009. Haplotypic background of a private allele at high frequency in the Americas. Molec Biol and Evol 26:995-1016.

Schroeder, KB, Schurr TG, Long JC, et al. 2007. A private allele ubiquitous in the Americas. Biol Letters 3:218-223.

Stojanowski CM, Johnson KM, Duncan WN. 2013. Beyond sinodonty: hemispheric, regional, and intracemetery approaches to studying dental morphological variation in the New World. In: Scott GR, Irish JD, editors. Anthropological Perspectives on Tooth Morphology: Genetics, Evolution, Variation. New York: Cambridge University Press. p 408-453.

Sutter RC. 1997. Dental Variation and Biocultural Affinities Among Prehistoric Populations from the Coastal Valleys of Moquegua, Peru, and Azapa, Chile. Ph.D. dissertation, Department of Anthropology, University of Missouri, Columbia.

Sutter RC. 2005. The prehistoric peopling of South America as inferred from epigenetic dental traits. Andean Past 7:183-217.

Tamm E, Kivisild T, Reidla M, et al. 2007. Beringian standstill and spread of Native American founders. PLoS ONE 9:1-6.
Turner CG II. 1971. Three-rooted mandibular first permanent molars and the question of American Indian origins. Am J Phys Anthropol 34:229-241.

Turner CG II. 1983. Dental evidence for the peopling of the Americas. In: Shutler Jr. R, editor. Early Man in the New World. Beverly Hills: Sage Publications. p 147-157.

Turner CG II. 1984. Advances in the dental search for Native American origins. Acta Anthropogenetica, 8: 23-78.

Turner CG II. 1985a. Dental evidence for the peopling of the Americas. Nat Geog Soc Res Rep 19: 573-596.

Turner CG II. 1985b. The dental search for Native American origins. In: Kirk R, Szathmary E, editors. Out of Asia: Peopling the Americas and the Pacific. Canberra: Australia National University. p 31-78.

Turner CG II. 1986. The first Americans: the dental evidence. Nat Geog Res 2:37-46.

Turner CG II. 1990. Major features of Sundadonty and Sinodonty, including suggestions about East Asian microevolution, population history, and Late Pleistocene relationships with Australian Aboriginals. Am J Phys Anthropol 82:295-317.

Turner CG II. 1992. New World origins: new research from the Americas and the Soviet Union. In: Stanford D, Day J, editors. Ice Age Hunters of the Rockies. Niwot, CO: University Press of Colorado. p 7-50.

Turner CG II. 2002. Teeth, needles, dogs, and Siberia: bioarchaeological evidence for the colonization of the New World. In: Jablonski N, editor. The First Americans: The Pleistocene Colonization of the New World. San Francisco: California Academy of Sciences. p 123-158.

Wang S, Lewis CM Jr., Jakobsson M, et al. 2007. Genetic variation and population structure in Native Americans. PLoS Genetics 3:2049-2067.

Waters MR, Forman SL, Jennings TA, et al. 2011. The Buttermilk Creek Complex and the origins of Clovis at the Debra L. Friedkin site, Texas. Science 311:1599-1603.

Wishart D. 2004. Clustan Graphics Primer. Middlesex: Allstar Services.

Young DE. 1988. The double burial at Horn Shelter: an osteological analysis. Central Texas Archaeologist 11:13-115. 